\title{
TITLE
}

\section{A Climate for Commerce: The Political Agronomy of Conservation Agriculture in Zambia}

\section{AUTHORS \\ Ola Tveitereid Westengen ${ }^{a}$, Progress Nyangab ${ }^{b}$ Douty Chibamba ${ }^{b}$, Monica Guillen Royo ${ }^{c}$, Dan Banik $^{d}$}

\begin{abstract}
The promotion of Conservation Agriculture (CA) for smallholders in Sub Saharan Africa is subject to ongoing scholarly and public debate regarding the evidence-base and the agendasetting power of involved stakeholders. We undertake a political analysis of CA in Zambia, which combines a qualitative case study of a flagship CA initiative with a quantitative analysis of a nationally representative dataset on agricultural practices. The current study moves from an investigation of the knowledge politics to an investigation of how the political agendas of the actors involved are shaping agrarian practices.

From its initial focus on $\mathrm{CA}$ as soil conservation and sustainable agriculture, the framing of the initiative has evolved to accommodate shifting trends in the policy arena. In tandem with the increased focus on climate adaptation, we detect an increasingly strong private sector-led modernisation agenda. The initiative has shifted its target group from the poorest smallholders to prospective commercial farmers, and has forged increasingly strong connections between its farmer-to-farmer extension network and the private input suppliers and service providers. The link between CA and input intensification is reflected in national statistics as a significant association between the practice of conservation tillage and usage of herbicides, pesticides and mineral fertilizer.

We argue that environmental and participation agendas are used to buttress CA as an environmentally and socially sustainable alternative agricultural development strategy, while the prevailing practice is the result of a common vision for a private sector-led agricultural
\end{abstract}


development shared between the implementing organisation, the donor and international organisations promoting a new Green Revolution in Africa.

\section{KEYWORDS}

Conservation Agriculture, Climate Smart Agriculture, green revolution, political agronomy, Norway, Zambia

\section{ABBREVIATIONS}

CA Conservation Agriculture

CAP Conservation Agriculture Programme

CFU Conservation Farming Unit

CSA Climate Smart Agriculture

DFID Department for International Development

FAO The Food and Agriculture Organisation of the United Nations

NEPAD New Partnership for Africa's Development

NORAD Norwegian Agency of Development Cooperation

RALS Rural Agricultural Livelihoods Survey

SSA Sub Saharan Africa

ZNFU Zambia National Farmers' Union

\section{CONTACT INFORMATION}

${ }^{a}$ Department of International Environment and Development Studies (Noragric), Norwegian University of Life Sciences, 1430 Ås, Norway;

${ }^{\mathrm{b}}$ Geography and Environmental Studies Department, School of Natural Sciences, University of Zambia, Pb. 32379, Lusaka, Zambia

${ }^{\mathrm{c}}$ Centre for Technology, Innovation and Culture, University of Oslo, Pb. 1108 Blindern, 0317 Oslo, Norway

${ }^{\mathrm{d}}$ Centre for Development and the Environment, University of Oslo, Pb. 1116 Blindern, 0317 Oslo, Norway 
Corresponding author: ola.westengen@nmbu.no

\section{AUTHOR BIOGRAPHIES}

Ola Tveitereid Westengen is Associate Professor in Agricultural Development at the Department of International Environment and Development Studies (Noragric), Norwegian University of Life Sciences.

Progress Nyanga is a Senior Lecturer at Geography and Environmental Studies Department, School of Natural Sciences, University of Zambia.

Douty Chibamba is a Senior Lecturer at Geography and Environmental Studies Department, School of Natural Sciences, University of Zambia.

Monica Guillen Royo is a researcher at the Centre for Technology, Innovation and Culture, University of Oslo, Oslo, Norway

Dan Banik is Profesor in Political Science at the Centre for Development and the Environment, University of Oslo, Oslo, Norway

\section{ACKNOWLEDGEMENTS}

This research is funded by a grant from the "Effect of Aid" (AIDEFFECT) call under the Global Partner (NORGLOBAL) programme of the Research Council of Norway. We are grateful to T.S. Jayne and Margaret Beaver at Michigan State University and Anthony Chapoto at Indaba Agriculture Research Institute (IAPRI) for providing access to the RALS12 data. We thank Olaf Erenstein at CIMMYT provided helpful comments on uptake figures and to Pål Vedeld, Tor A Benjaminsen and three anonymous reviews for incisive and useful comments to earlier versions of this paper. 


\section{INTRODUCTION}

This paper is a contribution to the ongoing debate regarding Climate Smart Agriculture (CSA) and Conservation Agriculture (CA) in Sub Saharan Africa. Using a Political Agronomy theoretical framework (Sumberg et al. 2014; Sumberg \& Thompson 2012) and a combination of a qualitative case study approach with quantitative analysis of a nationally representative dataset, we analyse how the framing of a flagship CA programme in Zambia has evolved and how this is reflected in programme implementation and in agrarian practices in the country.

The increased focus on the negative impact of climate change and the associated need for adaptation of agronomic technology and practices has led to a push for CSA in international development cooperation (Lipper et al. 2014). The set of practices termed 'conservation agriculture' has become one of the most prominent CSA approaches (Giller et al. 2015; Powlson et al. 2016; Fowler \& Rockstrom 2001; Baudron et al. 2015). The basic component of CA is minimum tillage (zero or reduced ploughing) and permanent soil cover in order to maintain and increase organic carbon in the soil and prevent erosion. According to FAO estimates the share of CA is approximately $22 \%$ in the United States and as high as $70 \%$ of the arable land in some Latin American countries (Richards et al. 2014). The high adoption rates in Latin America have provided a rationale for international development actors to promote $\mathrm{CA}$ as a development strategy for smallholder farmers in Sub Saharan Africa (SSA). However, after about three decades of active promotion of CA in SSA, the adoption rate is still low and many aspects of CA are currently contested in the academic literature (Sumberg \& Thompson 2012).

Proponents portray CA as an environmentally sustainable alternative to conventional approaches to agricultural development, whereas critics question the evidence base as well as the manner of which research and promotion of CA is undertaken. At one level, the discussion of the evidence is a normal academic debate in which claims are made in the peer-reviewed agronomy literature based on experiments and observations. There is, for example, considerable debate over whether or not CA mitigates climate change by sequestering organic carbon in soils (Hobbs \& Govaerts 2010; Powlson et al. 2016; Lal 2004). In addition, there are considerable differences in the findings on the effect of CA on yield and on its applicability in different farming system contexts (Pittelkow et al. 2015). The socio-economic literature on the uptake and adoption of CA is 
similarly a locus of conflicting evidence (Ngoma et al. 2016; Arslan et al. 2014; CFU 2013). However, such debates go beyond the 'standard' channels for scientific exchange and are visible on websites and CA promotion material across the world; non-governmental organisations and philanthropists have weighed in with claims regarding the virtues of CA and are often explicitly critical towards the research findings they disagree with (Sumberg \& Thompson 2012; Andersson \& Giller 2011).

This contestation over the scientific basis has spurred a scholarly meta-level debate about the 'knowledge politics' of CA. The highly-cited paper Conservation agriculture and smallholder farming in Africa: The heretics' view (Giller et al. 2009) kicked off this new strand of critical CA literature. The authors not only showed that the empirical base for CA's suitability for smallholders in Africa is conflicting, but also contended that CA is surrounded "with such strong advocacy that critical debate is stifled" (Giller et al. 2009, pp 23). The knowledge politics literature has shown that the narrative and claims on the success of CA by the actors involved has shifted in response to trends and priorities in international development policies and agendas (Whitfield et al. 2015b; Giller et al. 2015; Andersson \& D'Souza 2014). Anderson \& Giller (2012) argued that the actors promoting CA in Zimbabwe are a "conglomerate of faith-based, science-based and policy organisations" that together form an "epistemic community" with considerable agenda-setting power in agricultural development. With a focus on Zambia, Whitfield et al. (2015) employed a political ecology narrative analysis and identified five historical "overlapping and accumulative" narratives in the promotion of CA. They argued that these narratives have been shaped by the shifting political agendas of an "advocacy coalition" formed by the development actors involved rather than by empirical evidence.

Our study moves from an investigation of the knowledge politics to an investigation of how the political agenda shapes actual change of agrarian practices. This is thus not an evaluation of CA's ecological, productive or socio-economic outcomes in Zambia, but rather an analysis of what type of agricultural development pathway it is a part of. By explicitly examining the processes of agrarian change resulting from CA promotion in Zambia, we address a gap in the political agronomy literature on CA, which hitherto has mainly focused on how the CA agenda is framed and on the mismatch between the framings and the available empirical evidence. Thus, 
whilst previous studies have highlighted the notion that CA promoters are political actors, this study focuses on how their political agenda is shaping agrarian change in Zambia.

This article proceeds as follows: First, we present the case studied as well as the theory and methods employed. Then we trace the framing of the CA promotion initiative and examine the characteristic features of the current, dominant framing. Following this, we use the nationally representative Rural Agricultural Livelihoods Survey (RALS) from the 2012 farming season (IAPRI 2012) to undertake a quantitative analysis of the associations between CA practices and the use of commercial inputs characteristic of 'modernised' agriculture. Finally, we relate our findings to the "contested agronomy argument" (Sumberg \& Thompson 2012) and discuss what the CA experience in Zambia reveals about the processes that render certain framings powerful, and thereby determine agricultural policy and direct agrarian change.

\section{CASE AND APPROACH}

Several development actors are involved with the promotion of CA in Zambia. These include NGOs, the Government of Zambia through the Ministry of Agriculture, regional and international organisations and multilateral and bilateral donor agencies. In terms of historical involvement and geographic scope, the most significant actor has arguably been the Conservation Farming Unit (CFU), which first introduced CA in Zambia in the late 1980s (Haggblade \& Tembo 2003). While CFU is associated with the Zambia National Farmers' Union (ZNFU), it has an autonomous status as a "Non-Profit Company limited by guarantee" (CFU 2015). From 1996 and until recently, the major funding agency for CFU's operations has been the Norwegian Agency of Development Cooperation (Norad). Since 2006, Norad has funded the Conservation Agriculture Programme of CFU over two phases: CAP I: 2006-2011 (NOK 146m) and CAP II: 2011-2016 (NOK 171m) (Norad 2014). These two programmes have promoted CA in a total of 19 districts in Zambia's Southern, Central, Eastern and Western Provinces and, according to Norad, has resulted in the adoption of CA by more than 180,000 farmers as of 2014 (Norad 2015). When Norway decided to close its embassy in Lusaka in early 2016, the UK Government through the Department for International Development (DFID) took over as the main funding agency for CFU. The CAP initiatives have thus continued as part of the $£ 25 \mathrm{~m}$ 
Climate Smart Agriculture Zambia (CSAZ) project planned by DFID for the period 2016-2020 (DFID 2016).

The backbone of CAP was its extension and training system. CA information and training was disseminated from CFU's headquarters by CFU field officers, through so-called 'Lead Farmers' who trained other farmers in a farmer-to-farmer extension network (CFU 2012). The Lead Farmers received a small remuneration (ZMK1600) in the form of electronic vouchers for agricultural inputs as well as a bicycle. ${ }^{1}$ Farmers who adopted CA received a 'starter pack' with cassava cuttings, sweet potato vines, legume seeds and seeds of the agroforestry tree Faidherbia albida. In addition to such modest input support, CAP programmes have been based on the assertion that participation in training and field days would be sufficient incentives to convince farmers to shift from conventional techniques to CA (CFU 2011, 2006). The CFU approach to CA was inspired by the approach developed by Brian Oldreive, a former Zimbabwean largescale tobacco farmer and founder of the organisation Farming Gods Way ${ }^{2}$ (Andersson \& Giller 2012). Up to this day, CFU uses Oldreive's term 'Conservation Farming' (CF) instead of CA. However, while CF originally referred to the use of planting basins and mulch cover as prescribed by Oldreive's organisation, $\mathrm{CF}$ in Zambia encompasses various minimum tillage practices from hand-hoe tilling to mechanized ripping, preferably in combination with mulching and crop rotation.

The CAPs are interesting cases for studying the promotion of CA in particular, and agricultural development in the name of Climate Smart Agriculture in general. As the pioneering (and largest) CA actor in Zambia, CFU belongs to what Whitfield et al. (2015) describe as the CA "core coalition" in Zambia. The CAPs are both large-scale and long-term compared with most NGO projects, and are thus more likely to have considerable long-term impacts on the development pathway of Zambian agriculture. The CAPs were important forerunners to the $€ 11 \mathrm{~m}$ Conservation Agriculture Scaling Up Programme (CASUP) (FAO 2013) implemented by FAO and funded by the European Development Fund (Whitfield et al. 2015a). In addition to influencing Zambian agricultural development, the CAPs have had regional impacts in SSA

\footnotetext{
${ }^{1}$ Vouchers are for predetermined inputs or equipment through participating suppliers/agro-dealer shops.

2 Farming Gods Way has since shifted name to Foundations for Farming.
} 
through the CFU/Norad initiative, the Conservation Agriculture Regional Programme (CARP) for the dissemination of CA to Uganda, Kenya, Malawi and Tanzania (Norad 2015). Norway has also influenced the global CSA agenda inter alia as co-chair during the establishing year of the Global Alliance for Climate Smart Agriculture (FAO 2016) and as a supporter of the African Union's NEPAD programme on Agriculture and Climate Change, with the vision to have at least 25 million smallholder households practicing CSA by 2025 (NEPAD 2016).

In this study, we draw on political agronomy (Sumberg et al. 2013; Sumberg \& Thompson 2012) as well as the antecedent fields of political ecology (Robbins 2011; Blaikie \& Brookfield 1987) and agrarian political economy (Bernstein 2016; Buttel 2001) to map and analyse the agendasetting and agricultural practices within the CAPs. The emerging field of political agronomy offers a useful theoretical lens for investigating the epistemological and political dimensions of development-oriented agronomy. Political agronomy is concerned with analysing how different actors involved in development oriented agricultural research and development (R\&D) frame research problems and solutions. In this study, 'framing' is defined as the manner in which problems and solutions are represented and structured: "Framing sets the stage for narratives or storylines about a given problem: how it has arisen, why it matters and what should be done about it" (Sumberg et al. 2013). According to the authors who coined the term, political agronomy relates to the fields of 'science and technology studies' (STS) and political ecology (Sumberg et al. 2014). Political ecology arose from a combination of "the concerns of ecology and a broadly defined political economy" (Blaikie \& Brookfield 1977, p. 17). Political ecology integrates analyses of political and economic power relations in analyses of human-environment relationships (Turner \& Robbins 2008). The focus of political agronomy and political ecology overlaps in studies of the Green Revolution agricultural development agenda and its displacement of local practices and other environmental and social impacts (Forsyth 2004). However, the relevance of political economy for political agronomy analyses goes beyond the link to political ecology; agrarian political economy represented by the "new rural sociology" and literature on agrarian political economy (Buttel 2001; Bernstein 2016) has had political analyses of technological and environmental change in farming as part of their research agenda 
since the $1970 \mathrm{~s}^{3}$. The "contested agronomy argument", central to political agronomy and our analysis here, posits that three influential development agendas emerging since the mid-1970s have reshaped development-oriented agronomy and its position in the public debate: the neoliberal project, the environmental agenda and the participation agenda (Sumberg et al. 2013; Sumberg \& Thompson 2012; Sumberg et al. 2014). This typology of formative agendas resonates with theories in agrarian political economy such as food regime analysis (Friedmann \& McMichael 1989) as well as rich theoretical traditions in the sociology of agriculture and development (Buttel 2001).

In this study, we apply mixed methods to investigate what kind of agrarian change CA is part of in Zambia today. We combine a qualitative analysis of the evolution of CAP's framing and practices with a quantitative analysis of the associations between CA practices and the use of other agronomic practices and technologies. The empirical basis for the qualitative aspect is a combination of document analysis, field observation and interviews with project management and farmers involved with the CAPs. Field visits were conducted by joint Zambian-Norwegian research teams in the Eastern and Central provinces (districts include Chipata and Petauke in the Eastern province and Mumbwa in the Central province) during June and November 2015. During field visits, we conducted interviews with farmers $(n=10)$ as well as with project management staff at all levels (field officers, regional managers and HQ staff and leadership) ( $\mathrm{n}=8)$. The farmers interviewed were purposefully selected in order to represent both lead and participant farmers in the CAPs, as well as non-participating farmers. We conducted the interviews on the farms, visited their fields and, with the owners' consent, recorded cropping practices and input use in field notes and digital photographs. We also interviewed the project managers on the donor side at the embassy in Lusaka $(\mathrm{n}=1)$ and at HQ in Oslo $(\mathrm{n}=2)$. The documents analysed include project proposals and reports $(n=7)$, external monitoring and evaluation reports $(n=3)$, internal evaluation reports $(n=3)$, as well as newspaper articles, press releases, webpages, manuals and other information material from the projects.

\footnotetext{
${ }^{3}$ See (Buttel 2001) for a thorough genealogy of the literature on the political economy of agriculture and development sociology.
} 
The empirical basis for the quantitative analysis is the RALS12 dataset from the Food Security Research Project (FSRP). The RALS12 data collection was supported by Michigan State University and led by Indaba Agricultural Policy Research Institute (IAPRI) in collaboration with the Central Statistical Office (CSO) and the Ministry of Agriculture (MAL) (IAPRI 2012). The RALS12 was carried out in 2012 based on a sampling frame from the 2010 Census of Housing and Population. With more than 8000 households included, it is representative both at the national and province level (IAPRI 2016). The RALS12 data is publicly available under the data sharing policy presented at the Zambia Food Security Research Project (FSRP) webpage (IAPRI 2012). The data consists of a number of sub-sets that we merged and analysed in SPSS v.22.0 (IBM 2013). We merged household level and field level sub-sets by creating new dummy variables when needed (e.g. a variable was coded 1 at the household level for households with one or several fields prepared with the techniques counted as CA tillage: Planting basins, zero tillage and ripping). All data merging was done based on at least three common variables to avoid matching errors. In order to test for associations between CA practices and input use and agronomic practices we used the common $t$-test and ANOVA.

\section{THE EVOLVING NARRATIVE}

In their analyses of the narratives that have underpinned CA promotion in Zambia, Whitfield et al. (2015) identified five pairs of problem and solution framings: 1) Land degradation - Soil and water conservation; 2) Rising input costs - Reducing input dependency; 3) Food insecurity Increased food production; 4) Emissions from agriculture and deforestation - Climate change mitigation; 5) Social marginalization - Empowerment. The authors argue that rather than being based on empirical evidence, these framings reflect agendas and trends in the development discourse. They do not move beyond the knowledge politics analysis to explore the link between the narratives and the agricultural development in Zambia, which they laconically describe as following a "relatively conventional high-input maize-based" development pathway (Whitfield et al. 2015, p. 140). In the following section, we disentangle the evolution of the CAP narrative from the general analysis of CA by Whitfield et al. (2015), in order both to evaluate the contention that $\mathrm{CA}$ is part of the conventional agricultural development and to investigate how this eventually has happened. We show that the evolution of the CAP narrative both resonates 
with Whitfield et al.'s analysis in some parts, and departs from it in others. In this departure lays what we see as the explanation for the apparent paradox between the "accumulated" narrative about CA as an alternative agricultural development strategy and its alleged "conventional" outcomes.

\section{CA as soil conservation}

The core objective of CA is conservation of soil fertility and erosion control. The original conceptualization of CF as CFU adopted it from Zimbabwe was also about soil health and soil conservation (Andersson \&d Giller 2011). The CAP I proposal submitted to Norad claimed that the project would contribute towards "setting smallholders on a path that liberates them from food insecurity, provides them with the basis to take advantage of economic opportunities and enables them to become custodians of Zambia's agricultural environment rather than its exploitive tenants" (CFU 2006, p. 16). This and other passages in the project proposals and reports portray the relationship between poverty and environment as a 'downward spiral' in which poverty results in environmental destruction which leads to more poverty. The Malthusian perspective in this argument has been problematized and either rejected or nuanced in much academic work on poverty and the environment (Scherr 2000; Koning \& Smaling 2005; Benjaminsen 2015). Soil erosion and land degradation is the subject of some of the defining works in political ecology such as Political Economy of Soil Erosion (Blaikie 1985), in which Blaikie showed that the major drivers of resource degradation in Nepal were economic and political and not due to smallholder farmers' mismanagement as portrayed in the project rationale. The evidence presented in the CAP project outputs to substantiate the claim that CA leads to better conservation of soil fertility in Zambia is anecdotal and short on peer reviewed references. On the contrary, independent monitoring and evaluation research of the CAPs has found no significant effect on soil organic carbon content between CA tilled fields and field under conventional tillage (Aune et al. 2012; Esser et al. 2016). With regard to the concept of "hardpan", meaning a hardened soil layer caused by ploughing, recent peer reviewed outputs concluded that there is "no scientific basis" for the existence of a hardpan caused by ploughing (Esser 2016). Furthermore, evidence presented in Giller et al. (2015) indicated that zero tillage practiced without mulching, which is often the case in Zambia since the crop residues are used as feed for livestock, may actually aggravate soil erosion problems. Instead of empirical evidence 
from the Zambian smallholder context, the rationale provided by CFU is a rather anachronistic reference to the dust bowl in the American Mid-West (CFU 2017, 2010b). As Andersson \& Giller (2011) point out, the dust bowl reference and the related preoccupation with soil degradation and conservation was also central for colonial officers a long time before the term CA was conceived. In the paper Soil Erosion, Conservationism and Ideas about Development: A Southern African Exploration, 1900-1960, William Beinart writes: "the welfare of the soil often emerges as the cutting edge of justification for intervention in peasant agriculture" (Beinart 1984). The proposal for the current phase of the CA programme engages a colonial rhetoric by linking the degradation to one ethnic group in particular: "Alongside rural to urban migration in Zambia, rural to rural migration is also commonplace particularly from the plateaus of Southern Province where the continuous use of the plough first introduced to Tonga farmers in 1911 has depleted the soils of large tracts of farm land. These households migrate locally or long distances and occupy regenerated or pristine woodland where they are able to temporarily reverse their misfortunes by exploiting fertility endowed by nature." (CFU 2015a, pp 4). Again, CFU does not provide references to empirical studies to underpin these claims. This lack of empirical evidence for the 'soil degradation' framing of the justification for the CAPs, together with the picture emerging from a broad range of literature on the political economy/ecology/agronomy of soil erosion points to the question of what the underlying agenda of CFU is. Answering this question requires turning to other parts of the framing.

\section{CA and input independence}

In the CAP I proposal, external inputs are criticized for being inappropriate for the majority of the smallholders targeted and for creating dependency. This assertion is linked to a critique of the government's input subsidy schemes for fertilizer and improved maize. The CAP I proposal claime that the government subsidies had led to a "forced marriage" between CF and mineral fertilizer and likewise criticized the focus on maize for being "fine-tuned to convert purchased fertilizer, particularly nitrogen, into carbohydrates" (CFU 2006, pp15). The exclusion of fertilizer and maize seeds from the input packages that were provided to participants in CAP I (CFU 2010a) was a direct expression of this position. CAP I also emphasized the importance of agroforestry with the 'fertilizer tree' Faidherbia albida as a strategy to make farmers less reliant 
on purchased nitrogen fertilizer. Furthermore, with regard to technology for preparing the fields and keeping weeds at bay, the CAP I proposal highlighted the relevance of hand hoe preparation for planting basins and weeding. At this early stage of the CAP programme, mechanization of the land preparation was not mentioned at all and herbicides were considered appropriate only for the $5 \%$ of the farmers that were characterized as financially secure. The promotion of alternatives to commercial inputs such as hybrid seeds, mineral fertilizer, herbicides and mechanization reflects the initial focus of CAP on the poorest smallholders as well as the environmental aid agenda pursued by donor agencies such as Norad.

The CAP I report published in 2010 and documenting the major impacts of the programme, shows that the emphasis on external inputs shifted with a change in target groups during the first phase of the programme. Accordingly, it was more challenging than originally envisaged to engage small-scale farmers as lead farmers, and it proved more fruitful to work with "less-risk averse, medium scale farmers" (CFU 2010a, p. 18). This shift in focus from poor smallholders to “emerging farmers" was accompanied by an increased emphasis on inputs - especially herbicides but also improved maize seeds and mineral fertilizer - as important factors when making demonstration plots. Regarding herbicides, the report indicated that CFU's work, among others, contributed to an alleged fivefold increase in herbicide sales in Zambia during the project period. A private sector commercialization scheme was introduced early in CAP I and 'agrodealers' and tractor owners were considered an important beneficiary group (CFU 2010a, pp16). This shift from low input to promotion of input-intensive practices, and the explicit focus on promoting the private sector rather than public sector institutions and policies shows that a private sector-led input intensification theory of change has been part of the CAPs from an early stage. When CAP II was planned, herbicides had become an essential element - and so had mechanization. CAP II involved an agreement with the tractor supplier John Deer, and towards the end of the project phase, this was touted as one of the major successes of the programme (CFU 2015b). In a report from 2015 titled CFU Success, Failures and Future Strategy (CFU 2014), it is clearly stated that the shift in emphasis from hand hoe based, low-input smallholder farmers to emerging farmers with access to herbicides and tractor ripping has been an intentional development. Thus, whilst the argument about independence from government-subsidized inputs has remained central, the emphasis shifted from promoting alternatives to external inputs to promoting alternative suppliers. 
CA as gender sensitive and climate smart agriculture for food security

In the case of the CAPs, the framing of CA as a way to mitigate climate change, increase food security and empower women is evident in different reports from Norad as well as the implementers - the CFU. There is, however, a difference between how these framings have been used compared to earlier framings. These narratives were brought in at later stages in the CAPs and are, to a larger extent than the conservation and (government) independence narratives, also accentuated by the donor. The CSA concept, combining international agendas on agriculture, food security and climate change, was the leading theme in the Norwegian government strategy Food Security in a Climate Change Perspective launched in 2012 (MFA 2012). The strategy covered the period 2013-2015 and was framed as "the Norwegian government's most important answer to the developing countries' demands for greater support for climate change adaptation" (MFA 2012, pp 2). Throughout the period of the strategy, CA promotion was the major approach on the ground in SSA: "The support to smallholder farmers has a strong emphasis on climate smart agriculture (CSA) practices, especially conservation agriculture (CA). These are tools for increasing agricultural yields while building resilience of small-scale farmers towards the impacts of climate change, and at the same time reducing carbon emissions through minimum soil disturbance" (Norad 2015). Moreover, the donor, through a newspaper op-ed, communicated to the Norwegian audience that CA is equivalent to CSA (Melby 2014). The implementers on their side have also taken on board the CSA framing, reflected in the current project name Climate Smart Agriculture Zambia (CSAZ). While the first CAP proposal stated that evidence for a link between climate stress and food insecurity was non-existent in Zambia (CFU 2006, pp 8), the link between the CA practice of early planting and allegedly higher household food security in seasons with erratic rainfall is central in CSAZ.

The gender impact and empowerment narrative has been part of the CAPs since their inception and the argument is that CA empowers women because it is less labour-demanding (CFU 2011, 2006; Norad 2015). The alleged reduced labour demand in CA, both for land preparation and weeding are, however, not well documented (Whitfield et al. 2015b). Reduced weeding presupposes the use of herbicides as reduced till is associated with a higher weed pressure than ploughing, and the reduced burden on women in land preparation is highly dependent on the type 
of reduced till practiced. Our focus group interviews revealed that, in cases where land preparation shifted from ploughing to permanent basins, the labour shifted from men to women since ploughing is considered a male job and hand hoe tilling to a large extent is a female role. In spite of this complex and input-and-technology contingent relationship between CA practices and gender empowerment, the Norad report Women, Gender and Conservation Agriculture concluded that "CA benefits women and should therefore be supported as part of the follow-up to the Norwegian strategy for women's' rights and gender issues". (Norad 2011, pp 3). In line with Whitfield et al.'s (2015) analysis, we find that the climate smart agenda with its focus on adaptation and increased food security, as well as the gender agenda, appear to be strategic framings in responses to international policy trends. However, while these framings play supportive roles, we identify an underlying agenda that can explain how CA has become what it is in Zambia today. We argue that a narrative about the need to respond to low productivity in traditional agriculture with input intensive modernisation in the context of "farming as business" has become the dominant storyline backing the CAPs.

\section{CA as business}

The linkages between the private sector and CFU as a development actor goes all the way back to the beginning of CF's promotion. When ZNFU, the commercial and medium-scale farmer union in Zambia, decided to start promoting CF to smallholders through CFUs work in 1996/97 they started to work with farmers in the commercial Dunavant Cotton's contract farmer network (CFU 2006). Dunavant Cotton was one of the private sector actors involved with CA in the postStructural Adjustment Programme (SAP) years (Haggblade \& Tembo 2003). The cooperation between the commercial cotton company and CFU continued and in the CAP II proposal they were involved as a partner in the pilot scheme, to offer mechanized tillage service. Towards the end of CAP II, CFU presented the "strengthening and broadening of private sector input supply networks and the testing and introduction of more advanced technologies" as a key approach and legacy of their work (CFU 2014, pp.22). CFU has taken the role as a facilitator of better linkages between private input suppliers and farmers. Maize varieties donated by different seed companies are used in demonstration plots, and during organized field days a range of "major agro-dealerships" are invited to present their products (CFU 2011). During our field visits, we 
observed that CAP lead farmers had advertisement signs for specific inputs on the outer walls of houses, and roadside fields had signposts advertising for conservation farming side by side with signs advertising for commercial inputs (Figure 1). During the last part of CAP II and in CSAZ, the links between CFU and the input suppliers have become more explicit and more closely tied to specific companies. In 2014, the multinational seed company Syngenta and CFU formally piloted a model in which the company has access to skilful former Lead Farmers to act as "community sales agents" or field sales agents for the company. Furthermore, in 2014 CFU entered into an agreement with a consortium of agrochemical and seed companies, including BASF and Pioneer Dupont, in which both "current and past Lead Farmers" are appointed as sales agents. A visible sign of the close ties between input suppliers and CA is that many lead farmers have signs advertising for specific seeds or other inputs on their farms.

The boundaries between CFU as an organisation and as a private sector actor have always been blurred. They do not portray themselves as a NGO, but a "Non-Profit Company limited by guarantee" (CFU 2015a, pp 18). The goals are to "scale up demand" and "create opportunities for the private sector to invest in deepening and expanding the reach of their input supply and marketing services". The purpose is to benefit outgrower schemes and create opportunities for commercial banks to expand financial services in order to gradually expand the penetration of the private sector services and reduce significance and dependency on public subsidy schemes (CFU 2015a, pp 17-18). Already in the CAP II proposal, Lead Farmers were to be "positioned to offer their services to cooperating agro-dealerships as commission-based community marketing agents and technical advisors with the support of the remaining CAP technicians" (CFU 2011, pp 5). Towards the end of CAP II, it was stated that "the importance of strong private sector ties and their relationship to the sustainability of the CF extension system has become increasingly emphasized" (CFU 2015). Thus, although the CAPs repeatedly state that the lead farmer structure collaborates well with the public extension system, the future envisioned is one of increasingly stronger private involvement in advisory services and the sale of agricultural technologies.

The donor support for this political position also increased during CAP II. The right-wing coalition government in Norway that took office in late 2013 began placing more emphasis on 
private sector development, and a larger faith in trickle-down effects than the preceding left-wing coalition government (Westengen \& Banik 2016). While the aforementioned "Food Security in a Climate Change Perspective" strategy (MFA 2012) launched by the left-wing coalition was continued under the new government, the focus shifted towards a greater emphasis on private sector-led development. In the preface to the first annual report of the strategy, the new Minister of Foreign Affairs from the conservative party wrote "In our view, agriculture is business. The Government is convinced that the private sector and public-private partnerships can play an important transformational role not only for smallholders, but also in the form of large commercial investments - as long as they operate within internationally agreed standards and norms." (Norad 2014, pp 3). The same message is evident in outputs from the embassy in Lusaka: "Small-scale agriculture must become businesses and private retailers must begin to see smallholders as customers" (Melby 2014, our translation).

The conflation of the Climate Smart Agriculture agenda and the 'agriculture as business' framing is evident in the press release from DFID for the launch of the current $£ 25 \mathrm{M}$ phase of the initiative in June 2016 (DFID 2016). The main activities of the programme are framed as follows:

- Training farmers in climate smart agriculture techniques, enabling them to understand the steps involved in applying the technology and the benefits they would get; and

- Facilitating commercial relationships between farmers and private sector providers of agricultural services and inputs such as use of machinery and herbicides - both of which are critical for the adoption and sustainability of climate smart agriculture practices.

In the next section, we follow CA to assess if the 'agriculture as business' framing is visible as an association between CA and use of commercial inputs at the field and household level.

\section{(FIGURE 1 ABOUT HERE)}

\section{CA BY NUMBERS AND ASSOCIATION}

Part of the answer to our research question on the type of agricultural development CA is a part of in Zambia can be found by studying adoption statistics. Whilst there is considerable variation in the reported uptake of CA, studies based on various nationally representative datasets indicate 
that in terms of uptake CA still plays a relatively limited role. Arslan et al. (2014) reported that in 2008 about $5 \%$ of the HHs practiced either zero tillage, planting basins or ripping on some of their land, a figure that had decreased between 2004 and 2008. Their study was based on panel data from two rounds of the Rural Incomes and Livelihood Surveys, capturing data on crop production, marketing and food consumption among about 5000 small-scale farmers. Ngoma (2016) used data from the annual crop forecast survey collected by MAL and CSO, with an annual sample of around 13600 households and found that $4.40 \%$ of the smallholders in Zambia used minimum tillage (basins and/or ripping) as the main tillage method for all field crop in 2014 compared to around $3.55 \%$ in 2010 (Ngoma et al. 2016).

The RALS dataset utilized in the current study is based on the most recent census (2010) and represents a third independent data source. As in most studies, we use reduced tillage (or minimum tillage) as a proxy for CA uptake. Since previous studies have found that the uptake of reduced tillage is partial, meaning that users only practice it on part of their land (Ngoma et al. 2016; Arslan et al. 2014; Aune et al. 2012), we focused on identifying the number of fields and area under conservation tillage (planting basins, zero tillage and ripping) vs. those under conventional tillage (conventional hand hoeing, ploughing, ridging, bunding, mounding). At the national level, we found that only about $2 \%$ of the fields were under CA tillage in 2012 (Table 1) and the average field size was $0.88 \mathrm{Ha}$ for CA-tilled fields and 0.68 ha for the non-CA tilled fields. In line with findings in previous studies, we find that the use of CA tillage varies between provinces and crops. Considering only maize fields in the Eastern province (where CA has been promoted since the early 1990s, and where Arslan et al. (2014) and Ngoma et al. (2016) found some of the highest uptake rates) we found that CA tillage was practiced on about $4 \%$ of the fields. In a recent report on the latest RALS survey results, IAPRI report that in the 2015 season reduced tillage was practiced on $5.3 \%$ of the fields nationally and $7 \%$ in Eastern province (IAPRI 2016). Thus, the figures on CA tillage usage varies between sample-frame and years, but both in the case of the crop forecast data analysed by Ngoma et al. (2016) and in the case of the RALS data, there is a slight increase in the uptake in 2014 and 2015 compared to the baseline years 2010 and 2012, respectively.

(TABLE 1 ABOUT HERE) 
It is important to underline at this point that our analyses of the RALS and other nationally representative surveys relate to the uptake of CA tillage in Zambia in general, and do not constitute an evaluation of the CAP impact per se. The figure of 61,000 smallholder farmers practicing CA-tillage nationally reported by Ngoma et al. (2016) deviates substantially from the figure reported by the CAP donor and implementer. The CAPs have reported an increasing number of adopters over a decade of implementation and the latest officially published figures state that 181041 farming households had adopted CA by 2014 (Norad 2015). This figure is based on a stratified sampling strategy in which areas in proximity to lead farmers are considerably more intensively sampled than those further afield (CFU 2013). The rationale for using this sampling strategy is that the CAPs "high influence" areas will have disproportionality more adopters than areas far from their lead farmers. The divergence between the national level estimate detected from the nationally representative datasets and the CAP figure of $22 \%$ uptake of reduced tillage are considerable, but a large divergence between national level adoption figures and figures from the promotion area is common when considering the diffusion of an innovation. The increasing trend detected in the nationally representative surveys as well as the high adoption claims reported in project outputs indicate that CA is an increasingly significant factor in Zambian agricultural development.

In order to test the claim that CA in Zambia has become part of a high input agricultural development, we explored whether the use of CA tillage is associated with increased external inputs and other input intensive practices. In table 2, we present the difference in technology use on fields and farms under conservation tillage and those under conventional tillage. The field level data used to generate table 2 are taken directly from the survey, while the household level data were prepared by transforming field level data to percentage of fields under conservation or conventional tillage per household.

The results show that conservation tillage practice is associated with higher use of certain external inputs than conventional tillage practices. Conservation tilled fields are associated with considerably more herbicide sprayings per year than fields under conventional tillage. In addition to the increased herbicide use, which is a common ingredient in CA as it is practiced globally, there is also significantly higher use of pesticides, mineral top dressing fertilizer and mechanized 
harvesting among those practicing CA tillage. There were 6 and 2 times as many sprayings with herbicides and pesticides, respectively in fields under conservation tillage compared to conventional fields $(\mathrm{p}<0.001)$, Furthermore, there was around 30\% more use of mineral top dressing per area $(\mathrm{p}<0.001)$ and mechanized harvesting (around 4 times more of the fields $(\mathrm{p}<0.001))$. In the case of improved seeds and basal mineral fertilizer, we found no significant difference in use.

\section{(TABLE 2 ABOUT HERE)}

\section{IN THE LIGHT OF POLITICAL AGRONOMY}

The results of the quantitative analysis reported above show that CA in Zambia is indeed associated with more intensive use of external inputs. Furthermore, our account of the evolution of the CAP framings shows how different framings have converged towards a private sector-led modernisation approach to agricultural development. In this section, we relate our findings to the "contested agronomy argument" and discuss what the CA experience in Zambia reveals about the processes that render certain framings powerful, and so determine agricultural policy and direct agrarian change. Looking across the historical framings of the CAPs, we discuss how the environmental agenda, the participation agenda and the neoliberal agenda have shaped CA in Zambia.

The environmental agenda

The environmental agenda is represented in the CAPs both in the degradation - conservation framing and in the climate smart agriculture framing described above. The soil degradation and conservation framing remains a central rationale in the current CAP narrative, while the climate change framing has become increasingly important as this issue has risen to prominence on the international development agenda. These framings have contributed to create an image of $\mathrm{CF}$ as an environmentally friendly alternative to conventional agricultural development that has "much in common" with organic agriculture (Conway 2012, pp 258). Indeed, CA is commonly cited as an example of both Sustainable Intensification and Agroecology (Rockström et al. 2017; Altieri et al. 2012). Relating to the environmental agenda has been important for the CAP actors in order to stay relevant vis-à-vis the international aid agenda, and to ensure support across the development community. However, as the historical political ecological perspectives on the 
degradation-conservation framing in the previous section shows, this argument has political connotations. The environmental agenda of soil erosion control is also an agenda of social and political control. Similarly, the climate change - CSA framing is also used politically when private sector-led agricultural modernisation is installed as the most effective solution to the urgent need to adapt. The political economy of CSA is already subject to public contestation and scholarly analysis pointing out that the dominant focus on market-based transformations may entrench already unequal power relations (Karlsson et al. 2017). Our analysis shows that the CSA shift of the CAP framing was followed by an opening up of the CAP extension system to enable private sector-actor access to CA farming communities. This pattern has parallels in other development projects using the environmental agenda as the rationale. For instance, conservation and eco-tourism projects are often introduced with a win-win narrative, while in practice they often lead to new enclosures and dispossession for poor resource users (Benjaminsen \& Bryceson 2012). When discussing the environmental agenda in relation to CA it is also necessary to take a closer look at the association between CA tillage and herbicide use. The CFU management expressed disdain over the herbicide-critical attitude met among some donors, and said that they "push herbicides" at the same time as they promote correct herbicide use through information manuals ${ }^{4}$. The link between agrochemicals and CA is by no means unique to CFUs approach. The advent of new herbicides such as Atrazine and Paraquat was one of the key factors that made reduced tillage attractive for farmers in the US (Plummer 2013), and on the American continent there is a clear link between reduced tillage and the use of commercial input packages consisting of the herbicide glyphosate and genetically modified glyphosate-resistant seeds (Powles 2010). Thus, while the 'soil conservation' and 'climate change mitigation and adaptation' arguments for CA square well with the environmental agenda, the agrochemical use is a clear departure from this agenda ushered in by Rachel Carson's Silent Spring in the 1960s.

The participation agenda

In the initial phase, the CAPs involved activities such as Farmer Field Schools (CFU 2006, pp 47) and a farmer-to-farmer extension system, and was clearly influenced by the participation agenda and the language of the "farmers first" movement (Chambers \& Thrupp 1994; Scoones et al. 2009). However, the structure of the CAP extension system and the current role of Lead

\footnotetext{
${ }^{4}$ Interview P. Aagard, CFU, Lusaka, June 2015.
} 
Farmers differs significantly from the role envisioned in the original participation agenda. CAP II introduced a simplified version of the CAP I extension model, replacing a two-pronged farmer extension network with a single layer of Lead Farmers charged with the job of disseminating the CF message. The CAP extension and training model has thus become a rather conventional extension model in which CFU staff disseminate messages from the head office through a "single line of command" reminiscent of the Training and Visit (T\&V) Extension model promoted by the World Bank in the 70s and 80s (Benor \& Baxter 1984, pp 9). Thus, instead of moving in the same direction as the farmers first and participation agenda, with the innovation systems-perspective (Klerkx et al. 2012; Scar 2012; Hall 2007), the CAPs have moved towards a commercial technology transfer model.

The neoliberal project

One of the most explicit reflections of the neoliberal project in the CAPs is the critique of stateled subsidy programmes, and the increasingly strong push towards establishing a private sector input supply system. This development echoes the position articulated in the Berg report published by the World Bank in 1981, arguing that state provision and subsidization of inputs and services for agriculture is an unsustainable fiscal burden causing market disruptions (Sumberg \& Thompson 2012). The neoliberal agenda underpinned the SAPs, which in the 1980s and 1990s led to the partial dismantling of the public agricultural research and extension system in many SSA countries, including Zambia (Easterly 2005; Birner \& Resnick 2010). The thinking behind these policies was that the private sector would be better able to deliver the services than the public sector. History has shown that the private sector moved in to fill the space left by the public sector only to a limited degree in the 1980s, and today it is generally recognized that the SAPs for agriculture left a research and extension gap (IAASTD 2009; WB 2007). This gap has since been partly addressed by a burgeoning NGO sector. As Ellis (2000) points out, the agendas of structural adjustment and market liberalization (the neoliberal project) "found strange echoes and unlikely allies" (Ellis 2000, pp 26) among scholars, activists and NGOs that sought to replace the top-down green revolution approach with actor-oriented and participatory approaches. This "strange" conflation of the neoliberal agenda and the participation agenda is evident in CAP outputs. 
The neoliberal agenda in Zambian agricultural development has arguably also been fuelled by considerable donor fatigue with the public extension system (Haug 1999), a notion that was also expressed in interviews with the Norwegian public servants interviewed for this study. In the case of the CAPs, the donor and the implementing organisation have thus found common ground in the critique of inefficient government services. It is an apparent paradox that social democratic Norway, which itself has strong government involvement in domestic agricultural development, supports a private sector led pathway in Zambia. However, Norwegian agricultural policy also displays a trend towards liberalization over the last decades. This development is summarized in the rural sociologist Almås’ From State-Driven Modernization to Green Liberalism 1920-2000 (2004) and illustrated in the latest White paper 11 (2016-2017) on Norwegian agricultural policy, which stresses the need for agriculture to become "more consumer and market oriented". In international development assistance, this trend is expressed in the new Green Revolution for Africa agenda articulated by influential development actors such as the World Bank (WB 2007), the Rockefeller Foundation, the Bill and Melinda Gates Foundation (DeVries \& Toenniessen 2002) and the G8 New Alliance for Food Security and Nutrition (G8 2014). This agenda differs from the first green revolution agenda by its strong emphasis on the private sector as the major driver of change (Dawson et al. 2016). The new Green Revolution for Africa is as such a case in point for the departure from the State led agricultural development agenda of the Green revolution in the 60s and 70s (Westengen \& Banik 2016). Norway has, especially under the right-wing government entering office in 2013, aligned its support to agriculture with this agenda by locating agriculture within its strategy for private sector development cooperation (MFA 2014), and by making it part of the mandate of the Norwegian Investment Fund for Developing Countries (Norfund). This trend is also illustrated in the recent White Paper 24 (2016-2017) on Norwegian development cooperation and the SDGs, in which the need for commercialization of SSA's agriculture is stressed.

\section{From knowledge politics to political economy}

The discussion above shows that the contested agronomy argument in political agronomy highlights central elements to understand the linkages between framing and practice in the case of the CAPs in particular and CA in SSA in general. The environmental agenda forms a raison $d^{\prime} \hat{e} t r e$ for $\mathrm{CA}$, and the participatory agenda has been a useful framing of the opposition to state- 
led agricultural development represented in the private sector modus operandi of the CAPs. Thus, we argue that rather than being an example of a development strategy appropriated by mainstream neoliberal development actors, the CAPs exemplify how the environmental and participation agendas are used to buttress CA as an environmentally and socially sustainable alternative agricultural development strategy in SSA. As an example of a private sector led modernisation approach to agricultural development, the story of the CAPs tallies both with the historical analysis in political agronomy and rural sociology (Busch 1981; Dale 1981) as well as with the world historical analysis in the political economy literature on food regimes (McMichael 2009; Bernstein 2016). The centrality of the demise of the state-led development approach and the rise of market-centred development is reflected in the title of Friedmann and McMichael's seminal article on food regime theory: Agriculture and the State System: The rise and fall of national agricultures (Friedmann \& McMichael 1989). A central question in current food regime debates is whether or not the period of neoliberal globalisation since the 1980s qualifies as a distinct food regime, compared to the post-WW2 regime in which the Green Revolution was characteristic. Emphasizing the importance of the "agentic role of the corporate sector" since the 1980s, McMichael argues that the current neoliberal world order rests on a corporate food regime (McMichael 2016). Friedmann sees more continuity and rather talks about the emerging corporate-environmental food regime (McMichael 2009; Friedmann 2005). Our analysis of the CAPs resonates with Friedmann's conceptualization and analysis of how the environmental agenda is being appropriated by corporate actors "A new round of accumulation seems to be emerging in the agro-food sector, based on selective appropriation of demands by environmental movements, and including issues pressed by fair trade, consumer health and animal welfare activists" (Friedmann 2005 pp 229). The linkage between use of corporate crop and herbicide packages and reduced tillage in the Americas is one example of how the environmental agenda is used by corporate actors. This study provides another example of such practices.

\section{CONCLUSION}

A political agronomic perspective highlights that organisations involved with agricultural $R \& D$ are political actors. While previous work on the politics of CA have focused on how knowledge 
is created, our contribution focuses downstream - on the specific types of development pathways that CA promotion is a part of. We conclude that the CA initiative supported by Norway in Zambia is part of the private sector-led green revolution approach that is currently dominant in agricultural development funded by donors and international agencies. Our analysis shows that while the epistemic community behind the CAPs has engaged alternative environmental and social development agendas in their framing of the projects, the actual outcome is a more inputintensive 'agriculture as business' development pathway, which primarily entices farmers with prospects to become commercial farmers and private sector input suppliers and service providers. These political economic outcomes of the implementation of the CSA and CA agenda warrant more critical research.

CA has become the one of the most commonly cited examples of a contested agronomy (Andersson \& Sumberg 2015; Andersson \& D’Souza 2014). While a heated and polarized debate can indeed obscure issues and hinder unbiased research (Thierfelder et al. 2015), it appears the debate has actually contributed to open up space for new perspectives and research agendas (Whitfield et al. 2015b). Examples of the latter are agronomists asking Where to Target Conservation Agriculture for African Smallholders? (Baudron et al. 2015) and socio-economists recommending a move from blanket recommendations for CA towards a more context-sensitive “multi-stakeholder adaptive learning process" (Erenstein et al. 2012, pp 201). Similarly, the focus on the knowledge politics of CA has opened up space for alternative agronomic approaches. Moreover, revisiting the politics of CA implementation has the potential for initiating a wider debate on the causes and instruments of, in addition to the motivation for agrarian change.

\section{REFERENCES}

Almås, R. 2004. From State-Driven Modernisation to Green Liberalism 1920-2000. In Almås, R. (ed.) Norwegian Agricultural History. Trondeheim: Tapir academic press.

Altieri, Miguel A, Fernando R Funes-Monzote, and Paulo Petersen. 2012. Agroecologically efficient agricultural systems for smallholder farmers: contributions to food sovereignty. Agronomy for Sustainable Development 32 (1):1-13. 
Andersson, Jens A, and Shereen D'Souza. 2014. From adoption claims to understanding farmers and contexts: A literature review of Conservation Agriculture (CA) adoption among smallholder farmers in southern Africa. Agriculture, ecosystems \& environment 187:116-132.

Andersson, Jens A, and Ken E Giller. 2011. On heretics and God's blanket salesmen.

Andersson, Jens A. and Sumberg, Jim. (2017). Knowledge politics in development-oriented agronomy, In, Sumberg, J. (ed). (2017). Agronomy for Development: The Politics of Knowledge in Agricultural Research. Abingdon: Routledge.

Arslan, Aslihan, Nancy McCarthy, Leslie Lipper, Solomon Asfaw, and Andrea Cattaneo. 2014. Adoption and intensity of adoption of conservation farming practices in Zambia. Agriculture, ecosystems \& environment 187:72-86.

Aune, Jens Bernt, Progress Nyanga, and Fred Håkon Johnsen. 2012. A monitoring and evaluation report of the Conservation Agriculture Project 1 (CAP1) in Zambia. Noragric, Norwegian University of Life Sciences.

Baudron, Frédéric, Christian Thierfelder, Isaiah Nyagumbo, and Bruno Gérard. 2015. Where to target conservation agriculture for African smallholders? How to overcome challenges associated with its implementation? Experience from eastern and Southern Africa. Environments 2 (3):338-357.

Beinart, William. 1984. Soil erosion, conservationism and ideas about development: a southern African exploration, 1900-1960. Journal of Southern African Studies 11 (1):52-83.

Benjaminsen, Tor A. 2015. Political Ecologies of Environmental Degradation and Marginalization.

Benjaminsen, Tor A, and Ian Bryceson. 2012. Conservation, green/blue grabbing and accumulation by dispossession in Tanzania. Journal of Peasant Studies 39 (2):335-355.

Benor, Daniel, and Michael Baxter. 1984. Training and visit extension. World Bank.

Bernstein, Henry. 2016. Agrarian political economy and modern world capitalism: the contributions of food regime analysis. The Journal of peasant studies 43 (3):611-647.

Birner, Regina, and Danielle Resnick. 2010. The political economy of policies for smallholder agriculture. World Development 38 (10):1442-1452.

Blaikie, Piers. 1985. The political economy of soil erosion in developing countries. Longman.

Blaikie, Piers, and Harold Brookfield. 1987. Land degradation and society. Methuen.

Busch, Lawrence. 1981. Science and agricultural development. Allanheld, Osmun.

Buttel, Frederick H. 2001. Some reflections on late twentieth century agrarian political economy.

Sociologia Ruralis 41 (2):165-181.

CFU. 2006. Reversing Food Insecurity and Environmental Degradation in Zambia Through Conservation Agriculture. The CAP I proposal. Lusaka, Zambia: Conservation Farming Unit. 
CFU. 2010a. Reversing Food Insecurity \& Environmental Degradation in Zambia Through Conservation Agriculture. Final programme report. Lusaka, Zambia: Conservation Farming Unit.

CFU. 2010b. Zambia Conservation Agriculture Programme (CAP) - a brief update, ed. Virginia Tech. Virginia, USA.

CFU. 2011. Conservation Agriculture Programme (CAP) Phase II. Final Proposal submitted to the Norwegian Embassy Lusaka

CFU. 2013. 2013 IMCS Broad Based Survey Highlights. Lusaka, Zambia.

CFU. 2014. CFU Successes, Failures and Future Strategy. Lusaka, Zambia: CFU.

CFU. 2015a. Climate Smart Agriculture Programme Zambia (CSAZ). Proposal. Lusaka, Zambia: Conservation Farming Unit.

CFU. 2015b. Reversing food insecurity and environmental degradation in Zambia through conservation agriculture, phase II. Semi-annual progress report. Lusaka, Zambia: Conservation Farming Unit.

CFU. 2017. CFU Webpage. Accessed 12.01. 2017.

Chambers, Robert, and Lori Ann Thrupp. 1994. Farmer first: farmer innovation and agricultural research. KARTHALA Editions.

Conway, Gordon. 2012. One billion hungry: Can we feed the world? Ithaca and London: Cornell University Press.

Dale, Christopher. 1981. Agricultural research as state intervention [Tobacco production, farm enterprise; Kentucky]. Science and agricultural development.

Dawson, Neil, Adrian Martin, and Thomas Sikor. 2016. Green revolution in Sub-Saharan Africa: Implications of imposed innovation for the Wellbeing of rural smallholders. World Development 78:204-218.

DeVries, J., and G. Toenniessen. 2002. Securing the harvest: Biotechnology, breeding and seed systems for African crops. New York, USA: CABI.

DFID. 2016. UK gives Zambia £25m to support conservation farming.

Easterly, William. 2005. What did structural adjustment adjust?: The association of policies and growth with repeated IMF and World Bank adjustment loans. Journal of development economics 76 (1):1-22.

Ellis, F. 2000. Rural livelihoods and diversity in developing countries. Oxford New York: Oxford University Press.

Erenstein, Olaf, Ken Sayre, Patrick Wall, Jon Hellin, and John Dixon. 2012. Conservation agriculture in maize-and wheat-based systems in the (sub) tropics: lessons from adaptation initiatives in South Asia, Mexico, and Southern Africa. Journal of sustainable agriculture 36 (2):180-206. 
Esser, Kjell Bjørgen. 2016. Hardpan and maize root distribution under conservation and conventional tillage in agro-ecological zone IIa, Zambia. African Crop Science Journal 24 (3):267-287.

Esser, Kjell Bjørgen, Progress Nyanga, Douglas Moono, Gerard Cornelissen, Vegard Martinsen, Jan Mulder, Victor Shitumbanuma et al. 2016. Conservation Agriculture Research and Evaluation Programme 2012-2015, Zambia (CAREP), ed. Faculty of Environmental Science and Technology Norwegian University of Life Sciences, Department of Environmental Sciences. Ås, Norway: Norwegian University of Life Sciences, Faculty of Environmental Science and Technology, Department of Environmental Sciences.

FAO. 2013. Scaling up conservation agriculture in Zambia. Rome, Italy: FAO.

FAO. 2016. Global Alliance for Climate Smart Agriculture. http://www.fao.org/gacsa/about/co-chairs/en/. Accessed 16.06.2017

Forsyth, Timothy. 2004. Critical political ecology: the politics of environmental science. Routledge. Fowler, Richard, and Johan Rockstrom. 2001. Conservation tillage for sustainable agriculture: an agrarian revolution gathers momentum in Africa. Soil and tillage research 61 (1):93-108.

Friedmann, Harriet. 2005. From colonialism to green capitalism: Social movements and emergence of food regimes. In New directions in the sociology of global development, 227-264. Emerald Group Publishing Limited.

Friedmann, Harriet, and Philip McMichael. 1989. Agriculture and the state system: The rise and decline of national agricultures, 1870 to the present. Sociologia Ruralis 29 (2):93-117.

Giller, Ken E, Jens A Andersson, Marc Corbeels, John Kirkegaard, David Mortensen, Olaf Erenstein, and Bernard Vanlauwe. 2015. Beyond Conservation Agriculture. Frontiers in Plant Science 6:870.

Giller, Ken E, Ernst Witter, Marc Corbeels, and Pablo Tittonell. 2009. Conservation agriculture and smallholder farming in Africa: the heretics' view. Field crops research 114 (1):23-34.

G8 2014. The New Alliance for Food security and Nutrition, Progress Report 2013-2014, ed. USDA. Haggblade, Steven, and Gelson Tembo. 2003. Conservation farming in Zambia. Intl Food Policy Res Inst.

Hall, Andy. 2007. Challenges to strengthening agricultural innovation systems: where do we go from here?

Hobbs, Peter R, and Bram Govaerts. 2010. How conservation agriculture can contribute to buffering climate change. Climate change and crop production:177-199.

IAASTD. 2009. Agriculture at a crossroads. International Assessment of Agricultural Knowledge, Science and Technology for Development (IAASTD): Synthesis Report. Washington DC, USA: Island Press. 
IAPRI. 2012. 2012 Rural Agricultural Livelihoods Survey (RALS). Zambia Food Security Research Project (FSRP) http://fsg.afre.msu.edu/zambia/survey.htm Accessed.

IAPRI. 2016. Rural Agricultural Livelihood Survey 2015. 2015 Survey Report ed. Indaba Agricultural Policy Research Institute (IAPRI) Central Statistical Office. Lusaka, Zambia: Indaba Agricultural Policy Research Institute (IAPRI).

IBM Corp. 2013 IBM SPSS Statistics for Windows, Version 22.0. Armonk, NY: IBM Corp.

Karlsson, Linus, Andrea Nightingale, Lars Otto Naess, and John Thompson. 2017. 'Triple wins' or'triple faults'? Analysing policy discourse on climate-smart agriculture (CSA).

Klerkx, Laurens, Barbara Van Mierlo, and Cees Leeuwis. 2012. Evolution of systems approaches to agricultural innovation: concepts, analysis and interventions. In Farming Systems Research into the 21st century: The new dynamic, 457-483. Springer.

Koning, Niek, and Eric Smaling. 2005. Environmental crisis or 'lie of the land'? The debate on soil degradation in Africa. Land use policy 22 (1):3-11.

Lal, Rattan. 2004. Soil carbon sequestration impacts on global climate change and food security. Science 304 (5677):1623-1627.

Lipper, Leslie, Philip Thornton, Bruce M Campbell, Tobias Baedeker, Ademola Braimoh, Martin Bwalya, Patrick Caron, Andrea Cattaneo, Dennis Garrity, and Kevin Henry. 2014. Climate-smart agriculture for food security. Nature Climate Change 4 (12):1068-1072.

Nationen. 2014. En revolusjon er i gang. 06.05.

McMichael, Philip. 2009. A food regime genealogy. The Journal of peasant studies 36 (1):139-169.

MFA 2012. Matsikkerhet i et Klimaperspektiv / Food Security in a Climate Perspective. Oslo, Norway: The Royal Norwegian Ministry of Foreign Affairs.

MFA 2014. Working together: Private sector development in Norwegian development cooperation. Meld. St. 35 (2014-2015) Report to the Storting (white paper) Summary: Norwegian Ministry of Foreign Affairs.

MFA (2016) White paper 11. (2016-2017) Endring og utvikling — En fremtidsrettet jordbruksproduksjon. https://www.regjeringen.no/no/dokumenter/meld.-st.-1120162017/id2523121/ Accessed 16.05.2017

MFA (2017) White Paper 24. (2016-2017) Felles ansvar for felles fremtid — Bærekraftsmålene og norsk utviklingspolitikk. https://www.regjeringen.no/no/dokumenter/meld.-st.-2420162017/id2547573/sec1 Accessed 16.05.2017

NEPAD. 2016. Concept Note 2nd Africa Climate Smart Agriculture Alliance Annual Forum "From Agreement to Action: Implementing African INDCs for Growth and Resilience in Agriculture", ed. NEPAD. Nairobi, Kenya: AU. 
Ngoma, H, BP Mulenga, and TS Jayne. 2016. Minimum tillage uptake and uptake intensity by smallholder farmers in Zambia. African Journal of Agricultural and Resource Economics 11 (4).

Norad. 2011. Women, Gender and Conservation Agriculture: Report from a fact finding mission, ed. Norad. Oslo, Norway: Norwegian Agency for Development Cooperation.

Norad. 2014. Food Security in a Climate Perspective, Annual Report 2013. Oslo, Norway: Norad.

Norad. 2015. Food security in a climate perspective, Annual Report 2014. Oslo, Norway: Norad.

Pittelkow, Cameron M, Xinqiang Liang, Bruce A Linquist, Kees Jan Van Groenigen, Juhwan Lee, Mark E Lundy, Natasja van Gestel, Johan Six, Rodney T Venterea, and Chris van Kessel. 2015. Productivity limits and potentials of the principles of conservation agriculture. Nature 517 (7534):365-368.

Powles, Stephen O Duke Stephen B. 2010. Glyphosate-resistant crops and weeds: now and in the future. Powlson, David S, Clare M Stirling, Christian Thierfelder, Rodger P White, and ML Jat. 2016. Does conservation agriculture deliver climate change mitigation through soil carbon sequestration in tropical agro-ecosystems? Agriculture, ecosystems \& environment 220:164-174.

Richards, Meryl, Tek Sapkota, Clare Stirling, Christian Thierfelder, Nele Verhulst, Theodor Friedrich, and Josef Kienzle. 2014. Conservation agriculture: Implementation guidance for policymakers and investors.

Robbins, Paul. 2011. Political ecology: A critical introduction. John Wiley \& Sons.

Rockström, Johan, John Williams, Gretchen Daily, Andrew Noble, Nathanial Matthews, Line Gordon, Hanna Wetterstrand, Fabrice DeClerck, Mihir Shah, and Pasquale Steduto. 2017. Sustainable intensification of agriculture for human prosperity and global sustainability. Ambio 46 (1):4-17.

Scar, EU. 2012. Agricultural knowledge and innovation systems in transition-a reflection paper. European Commisssion, Standing Commitee on Agricultural Research-Collaborative Working Group on Agricultural Knowledge and Innovation System (CWG AKIS), Brussels.

Scherr, Sara J. 2000. A downward spiral? Research evidence on the relationship between poverty and natural resource degradation. Food Policy 25 (4):479-498.

Scoones, Ian, John Thompson, and Robert Chambers. 2009. Farmer first revisited. Rugby: Practical Action.

Sumberg, James, and John Thompson. 2012. Contested agronomy: Agricultural research in a changing world. Routledge.

Sumberg, James, John Thompson, and Philip Woodhouse. 2013. Why agronomy in the developing world has become contentious. Agriculture and Human Values 30 (1):71-83.

Sumberg, James, John Thompson, and Philip Woodhouse. 2014. Political Agronomy. Encyclopedia of Food and Agricultural Ethics:1502-1508. 
Thierfelder, C, Frédéric Baudron, and Isaiah Nyagumbo. 2015. Conservation agriculture in Africa: where does it fit? In CIMMYT Opinion, ed. CIMMYT.

Turner, BL, and Paul Robbins. 2008. Land-change science and political ecology: Similarities, differences, and implications for sustainability science. Annual Review of Environment and Resources 33:295316.

Washington Post. 2013. No-till farming is on the rise. That's actually a big deal.

WB. 2007. Agriculture for Development: World Development Report 2008. World Bank.

Westengen, Ola Tveitereid, and Dan Banik. 2016. The State of Food Security: From Availability, Access and Rights to Food Systems Approaches. In Forum for Development Studies: Taylor \& Francis.

Whitfield, Stephen, Jami L Dixon, Brian P Mulenga, and Hambulo Ngoma. 2015a. Conceptualising farming systems for agricultural development research: cases from Eastern and Southern Africa. Agricultural Systems 133:54-62.

Whitfield, Stephen, Andrew J Dougill, Jen C Dyer, Felix K Kalaba, Julia Leventon, and Lindsay C Stringer. 2015b. Critical reflection on knowledge and narratives of conservation agriculture. Geoforum 60:133-142. 


\section{TABLES AND FIGURES}

Table 1. Number of fields under conservation tillage

\begin{tabular}{|l|l|l|l|l|}
\hline Fields & All crops & Maize fields & $\begin{array}{l}\text { Eastern } \\
\text { province (all } \\
\text { fields) }\end{array}$ & $\begin{array}{l}\text { Eastern } \\
\text { province (maize } \\
\text { fields) }\end{array}$ \\
\hline $\begin{array}{l}\text { Conventional } \\
\text { tillage }\end{array}$ & $21890(98 \%)$ & $8853(97.7 \%)$ & $5805(97.2 \%)$ & $2175(96 \%)$ \\
\hline $\begin{array}{l}\text { Conservation } \\
\text { tillage }\end{array}$ & $450(2 \%)$ & $213(2.3 \%)$ & $165(2.8 \%)$ & $85(4 \%)$ \\
\hline Total & $\begin{array}{l}22340 \\
(100 \%)\end{array}$ & $9066(100 \%)$ & $5970(100 \%)$ & $2264(100 \%)$ \\
\hline
\end{tabular}

Table 2. Comparison of input use and agronomic practices between conventional and conservation tillage farms at the field and household level. This table presents results of $t$-tests with level of significance of the difference in averages of the two groups in separate columns $* * * p<0.001 * * p<0.01$ and $* p<0.05$

\begin{tabular}{|l|l|l|l|l|l|l|}
\hline \multicolumn{2}{|c|}{ Field level (N=22340 fields) } & \multicolumn{2}{l}{ Household level (N=8840 } \\
households)
\end{tabular}




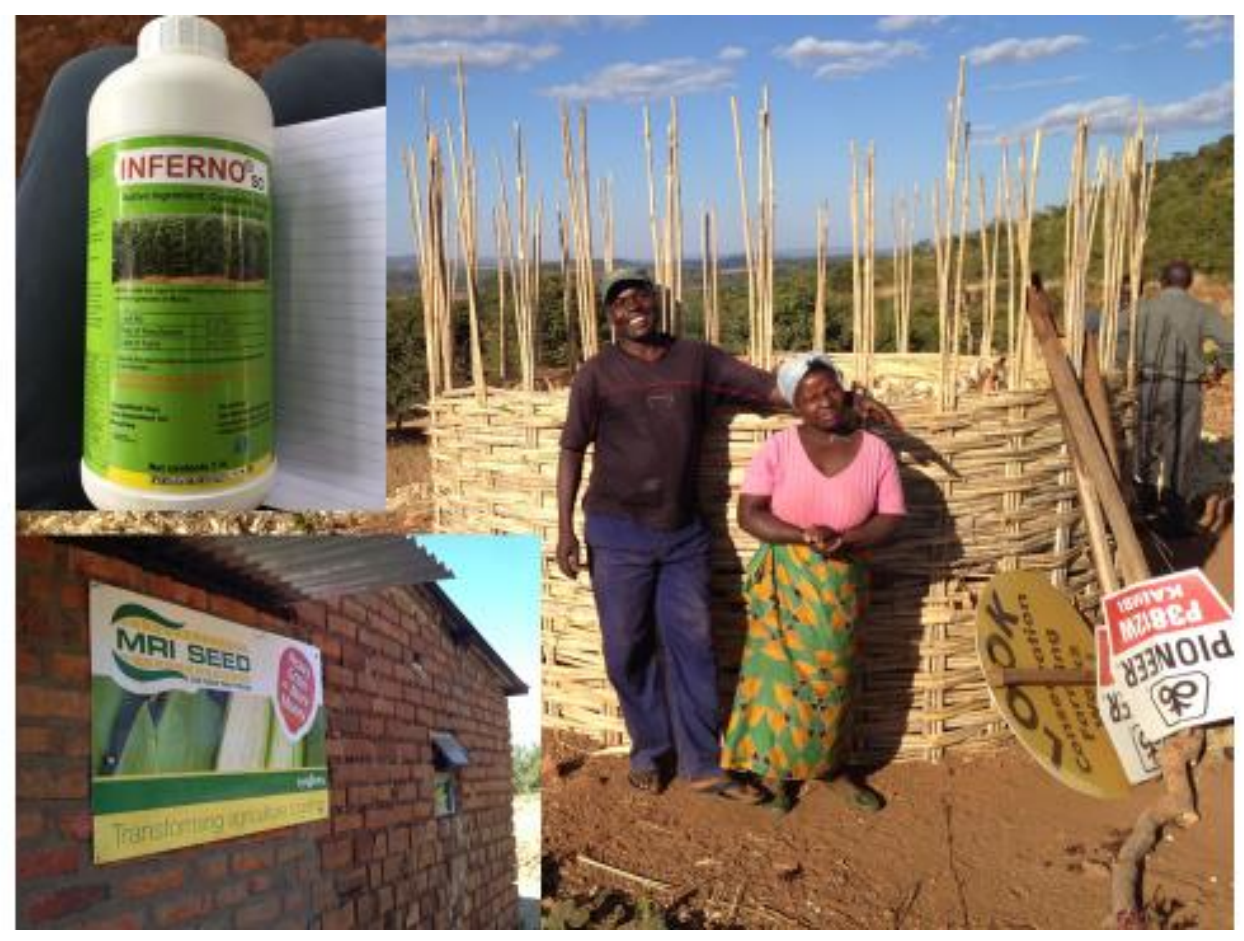

Figure 1. Farmers practicing conservation agriculture posing in front of their harvest. The dismantled signposts in the main picture illustrates overlap between CAP participation and promotion of commercial inputs. The insets shows herbicide and improved seed brands promoted by two lead farmers interviewed for this study. 